Acta Technologica Agriculturae 3

Nitra, Slovaca Universitas Agriculturae Nitriae, 2020, pp. 105-110

\title{
EFFECTIVE PRE-TREATMENTS FOR ENHANCEMENT OF BIODEGRADATION OF AGRICULTURAL LIGNOCELLULOSIC WASTES IN ANAEROBIC DIGESTION - A REVIEW
}

\author{
Fatemeh RAHIMI-AJDADI*, Masoomeh ESMAILI \\ University of Guilan, Rasht, Iran
}

\begin{abstract}
Agricultural crop residues like stems, straws and leaves are valuable resources for biofuel production, especially methane, due to anaerobic digestion. Biogas from agricultural lignocellulosic wastes is capable of attaining sustainable energy yields without environmental pollution. Farmers in many developing countries burn these wastes throughout their fields, imposing environmental hazard due to emission of greenhouse gases. The main problem in this field is the recalcitrance of the agricultural lignocellulose waste that limits its enzymatic degradation and hydrolysis efficiency and consequently decreases biogas production. Therefore, efficient pre-treatments prior to anaerobic digestion are essential. Various pre-treatment methods are used for increasing the anaerobic digestibility of lignocellulose biomass, such as physical (mechanical, thermal, etc.), chemical, biological and combined pre-treatments. This paper reviews different pre-treatments used in anaerobic digestion for the agricultural lignocellulosic wastes and explains the advantages and disadvantages of each. The most frequently used pre-treatments for main agricultural wastes in process of biogas production are also introduced.
\end{abstract}

Keywords: biogas; hydrolysis; lignin; methane

Currently, the most used energy supply in the world is fossil fuel that has some disadvantages, such as limited resources, growing price trends and environmental pollution. The issue of waste management is one of the main environmental challenges (Hlinka et al., 2019). Consequently, global attention is concentrated on finding the alternative energy resources, which would be both economically and environmentally acceptable (Zilouei and Taherdanak, 2015). Biofuels predominantly produced from biomass have the potential to be the reliable alternate energy resource that is considered the fourth largest energy resource in the world (Rajput and Visvanathan, 2018). Lignocellulosic biomass is more acceptable, because it has no nutritional value for humans. Biogas made of lignocellulosic biomass has many other advantages, such as low-cost feedstock and its abundance. In addition, it represents a way to manage the large amounts of agricultural and forest residues that are annually produced. In many developing countries, farmers burn these wastes in their fields, which results in environmental pollution due to emission of greenhouse gases. Biogas from lignocellulosic biomass is capable of attaining the sustainable energy yields without damaging the environment only when it is generated through anaerobic digestion and recovered properly (Chojnacka et al., 2015). Additionally, it is highly recommended to add crop residues to livestock excrement for purposes of digestion process (Kažimírová et al., 2018). The general equation for anaerobic digestion is given in Eq. 1:
$\mathrm{C}_{x} \mathrm{H}_{y} \mathrm{O}_{z}+\left(x-\frac{y}{4}-\frac{z}{2}\right) \mathrm{H}_{2} \mathrm{O} \rightarrow\left(\frac{x}{2}-\frac{y}{8}-\frac{z}{4}\right) \mathrm{CO}_{2}+\left(\frac{x}{2}-\frac{y}{8}-\frac{z}{4}\right) \mathrm{CH}_{4}(1)$

Eq. 2 is specifically for cellulose (Rai, 1986)

$$
\left(\mathrm{C}_{6} \mathrm{H}_{10} \mathrm{O}_{5}\right)_{n}+n \mathrm{H}_{2} \mathrm{O} \rightarrow 3 n \mathrm{CO}_{2}+3 n \mathrm{CH}_{4}
$$

The problem is that there is a main limitation in degradation phase of lignocellulosic biomass. Due to the recalcitrant nature of lignocellulosic biomass in terms of anaerobic digestion, it is essential to seek different types of pre-treatment methods for more efficient and economic anaerobic digestion. Pre-treatments can solve the issue of low digestibility of substrates and make them degrade more efficiently in biogas process. The relative amount of lignocellulosic compounds varies in different types of agricultural biomass. Consequently, the available substrates have different properties and usage of a specific pre-treatment is of extreme importance in order to increase digestibility and biogas production (Venturin et al., 2019). The purpose of this paper is to present the major types of pre-treatment for lignocellulosic wastes of agricultural crops.

\section{Mechanical pre-treatments}

The most basic method for physical pre-treatment is mechanical pre-treatment. It reduces the biomass particle size and is always applied prior to other pre-treatment methods to enhance their effect. It includes milling; grinding; chipping; etc. Reduction of the lignocellulosic

Contact address: Fatemeh Rahimi-Ajdadi, University of Guilan, Faculty of Agricultural Sciences, Department of Agricultural Mechanization Engineering, Rasht, Iran, e-mail: rahimi a@guilan.ac.ir 
biomass particle size increases the accessible surface area, reduces the degree of cellulose crystallinity, and decreases the degree of cellulose polymerization (Yuan et al., 2014). The main disadvantage of mechanical pre-treatment is that, if the biomass moisture content is high, the energy consumption necessary to exercise it, is also very high (Tu and Hallett, 2019). However, such pre-treatments are more advantageous specially than chemical pre-treatments, because they produce neither toxic or inhibitory materials nor complex molecules that are difficult to digest (Venturin et al., 2019). Extrusion is also one of the efficient mechanical pre-treatment methods for lignocellulosic materials that results in a lower bulk density, higher specific porosity, higher water-holding capacity and better biodegradability (Gu et al., 2015). Substrate can be placed under a pressure of up to 300 bars at temperatures from 60 to $300{ }^{\circ} \mathrm{C}$, depending on the final consistency required (Montgomery and Bochmann, 2014). High shear force results in efficient mixing that can effectively enhance the anaerobic digestion efficiency (Gu et al., 2015), making this method more efficient than other physical pre-treatment methods. Panepinto and Genon (2016) showed that extruder utilization can lead to an improvement of up to $15 \%$ in biogas yield and also an improvement in terms of energy consumption of up to $6.5 \%$. Menardo et al. (2015) reported that by means of extrusion, organic matter degradation was enhanced and methane production was significantly increased by as much as $16 \%$. Hjorth et al. (2011) reported that the methane production increased significantly by $18-70 \%$ using extrusion as a pretreatment for five types of agricultural wastes. However, several disadvantages of the extrusion lie in high energy consumption, high maintenance costs due to abrasion of screws and high sensitivity to stones (Montgomery and Bochmann, 2014).

Thermal pre-treatment uses thermal energy to increase the molecular agitation with the aim to promote the hydrolysis and, consequently, increases the methanogenic production in a shorter period of time. In terms of thermal pre-treatment, lignocellulosic biomass is subjected to heat ranging from 50 to $240{ }^{\circ} \mathrm{C}$ at a certain pressure. Thermal pre-treatment at temperatures of $160{ }^{\circ} \mathrm{C}$ and higher results in the solubilisation of hemicellulose and lignin (Xie et al., 2011). The disadvantage of higher temperatures (exceeding $160{ }^{\circ} \mathrm{C}$ ) is that produced phenolic compounds have inhibitory or toxic effects on methanogenic bacteria (Xie et al., 2011). Thermal pre-treatments dependent on the type of heating method can be named as hydrothermal pre-treatment and steam explosion. In this review, thermal pre-treatment methods are understood as physical pretreatments, while hydrothermal and steam explosion are considered physiochemical pre-treatments. Ultrasonic pre-treatment increases the total hydrolysis yield of the lignocellulosic biomass through increasing the surface area and reducing the degree of polymerization. The effect of ultrasonics is based on monolithic cavitation beyond the human audio range. The breakdown of cavitation bubbles during the sonication changes the chemical structure by the creation of free radicals (Grönroos et al., 2004). However, the higher sonication power level has adverse effect on the pre-treatment process (Karuppiah and Azariah, 2019). In their study on ultrasonic pre-treatment of rice hulls, Yu et al. (2009) obtained the net yields of total soluble sugar of $31.8 \%$ and glucose of $32.2 \%$ in contrast to control group values of $6.9 \%$ and $7.6 \%$.

In recent years, microwave-assisted pre-treatment methods have been demonstrated as one of the most effective and promising methods for biomass conversion due to cleavage of $\beta-1,4$-glucan bonds, increasing the accessible surface area and reducing the crystallinity of cellulose (Chandra et al., 2012a). There are several disadvantages related to ultrasound and microwave methods, such as production of inhibiting by-products ( $\mathrm{Li}$ et al., 2013); high energy consumption (Zeynali et al., 2017); and complex operation procedures. Table 1 shows the researches performed on several physical pre-treatments of main agricultural crops.

\section{Chemical pre-treatments}

Chemical pre-treatment is the most utilized method for pre-treating of lignocellulosic substrates. The main function of the majority of chemical pre-treatments lies in the destruction of rigid or complex structures of lignocellulosic biomass (Venturin et al., 2019). In comparison to other pre-treatment methods, chemical pre-treatments are advantageous because of their easiness, fastness, and effectiveness. They mainly include dilute-acid; alkaline; ionic liquids; and ozone pre-treatments.

Strong concentrated acids can hydrolyse the hemicellulose and solubilize lignin; nevertheless, their use is limited because they produce undesirable by-products, such as furfural as well as its derivatives that inhibit the anaerobic digestion process (Mussoline et al., 2013). In addition, there are certain other disadvantages - chemicals used are extremely corrosive and high-cost materials are

Table 1 Mechanical pre-treatments used for biogas production from certain agricultural substrates by means of anaerobic digestion

\begin{tabular}{|c|c|c|c|c|c|}
\hline Crop & Category & Pre-treatments & $\begin{array}{c}\text { Methane/biogas } \\
\left.\text { (mL·gVS }{ }^{-1}\right)\end{array}$ & $\begin{array}{c}\text { Increased } \\
(\%)\end{array}$ & References \\
\hline Rice & milling & $5-10 \mathrm{~mm} ; 6 \% \mathrm{NaOH} ; 20^{\circ} \mathrm{C} ; 21$ day & 520 & 44 & He et al., 2008 \\
\hline Corn & milling & 5-10 mm; $2 \% \mathrm{NaOH} ; 10,20{ }^{\circ} \mathrm{C} ; 3$ day; SLR ${ }^{*} 1: 9$ & $207.9 ; 233.0$ & $56 ; 75$ & Zheng et al., 2010 \\
\hline Wheat & thermal & $40,100,160^{\circ} \mathrm{C} ; 30 \mathrm{~min}$ & $201 ; 199 ; 224$ & $0 ; 0 ; 10$ & Sambusiti et al., 2013 \\
\hline Sorghum & thermal & $40 ; 100 ; 160^{\circ} \mathrm{C} ; 30 \mathrm{~min}$ & $242 ; 282 ; 273$ & $0 ; 5 ; 2$ & Sambusiti et al., 2013 \\
\hline Maize & ultrasound & Machine J.P Selecta Ultrasons $110 \mathrm{~W}, 3 \mathrm{~min}$ & 710 & 41 & Wang et al., 2011 \\
\hline
\end{tabular}

* - solid loading rate 
necessary for building of the reactor when using this type of pre-treatment (Zheng et al., 2014). Simultaneously, dilute acids $\left(4 \% \mathrm{w} \cdot \mathrm{w}^{-1}\right)$ are commonly used in applications and researches. The main mechanism of dilute acid pre-treatment lies in the solubilization of hemicellulose (Montgomery and Bochmann, 2014) by breaking ether bonds in lignin/ phenolics-carbohydrates complexes without dissolving lignin, which helps to increase the biogas production. Frequently used acids for lignocellulosic biomass are $\mathrm{H}_{2} \mathrm{SO}_{4}$ $\mathrm{HNO}_{3}$ and $\mathrm{H}_{3} \mathrm{PO}_{4}$. Antonopoulou and Lyberatos (2013) reported that the combination of acids with thermal pretreatment caused an increase in soluble carbohydrate's concentration. Alkaline pre-treatment is one of the most commonly used pre-treatment methods that usually uses $\mathrm{NaOH}, \mathrm{Ca}(\mathrm{OH})_{2}, \mathrm{KOH}$, and ammonia. An important aspect of alkaline pre-treatment is that the substrate itself consumes some of the alkali (Chen et al., 2014). Alkaline pretreatments are more effective than acidic ones because they change the structure of lignin and increase the accessibility to holocelluloses (Sambusiti et al., 2013). However, there are also several disadvantages - high alkali concentration in digester and high cost of chemical material. Alkaline pre-treatments are performed by bases such as sodium; potassium; calcium; and ammonium hydroxides. Literature review shows that sodium hydroxide (Salehian et al., 2013) and calcium hydroxide are the two most frequently utilized alkalis in alkaline pre-treatment. However, their utilization consumes much more time (order of hours or days) than acid pre-treatment (minutes or seconds) (Sambusiti et al., 2013). Calcium hydroxide may be preferable than sodium and potassium hydroxides because it is a much cheaper reagent, safer, more environmentally friendly, and more easily recovered (Singh et al., 2015). In addition, $\mathrm{Ca}^{2+}$ has no inhibitory effect on anaerobic digestion (Chen et al., 2008). Nevertheless, it may not improve the biomass digestion significantly alone because it is known as a weak alkali (Ji et al., 2017). Generally, alkaline pre-treatments are used along with other pre-treatments like thermal, hydrothermal, etc.

lonic liquids are salts that are in the liquid phase at a temperature as low as room temperature (Venturin et al., 2019). In fact, using ionic liquid pre-treatment results in producing much less crystalline cellulose, causing it to facilitate and accelerate enzymatic hydrolysis (Zhao et al., 2009). Ionic liquids can be applied under mild conditions and their reactions result in negligible vapour pressures; therefore, they can be recovered and reused after the process (Tu and Hallett, 2019). Ozone is a strong oxidant and the ozonation process can break cell wall, what leads to more soluble and easily biodegradable lignocellulosic biomass (Karuppiah and Azariah, 2019). Consequently, substrates can be easily accessed and assimilated by anaerobic microorganisms, resulting in improved efficiency of hydrolysis and, in turn, anaerobic digestion. The advantage of ozone pre-treatment is that it can be carried out at room temperature and atmospheric pressure. However, this process requires large amounts of ozone, resulting in high cost. Table 2 shows the studies on different chemical pretreatments of several agricultural crop wastes processed by means of anaerobic digestion.

\section{Combined pre-treatments}

Results of previous studies show that the combination of pre-treatments can result in much better biogas yield and the effect of pre-treatment alone is limited (Gu et al., 2015). Hydrothermal pre-treatment - as one of the most efficient physicochemical pre-treatments - is performed in hot compressed water. It is widely recognized as a green method without potential utilization of chemicals and resulting pollution and thus gains high importance in the $21^{\text {st }}$ century (Chandra et al., 2012a). Its process allows water molecules to penetrate lignocellulose network, removes most of the hemicellulose and part of lignin in biomass via degrading them into soluble fractions, and loosens the recalcitrant structure. One of the advantages of hydrothermal pre-treatment is that it performs a selective hydrolysis of hemicellulosic fraction by using a cheap reagent. Simo et al. (2016) studied the effect of hydrothermal pre-treatment on sugarcane bagasse. They found that the hydrothermal pre-treatment showed hydrolysis yield of $42.86 \%$, increasing the amount of lignin from $22 \%$ to $47 \%$ of dry matter without degradation of cellulose. Wang et al. (2018) performed hydrothermal pre-treatment on rice straw and examined the temperatures of $90,150,180$ and $210^{\circ} \mathrm{C}$ for $15 \mathrm{~min}$ (heating rate of $10^{\circ} \mathrm{C} \cdot \mathrm{min}^{-1}$ ). Their results showed a reduction of $30 \%$ in biogas yield at $210{ }^{\circ} \mathrm{C}$. According to their results, hydrothermal pre-treatment was not technically recommended for biomethane production, especially at higher temperatures; however, lower temperatures were potentially suggested. Costa et al. (2014) compared the effect of hydrothermal, acid and alkaline pre-treatments on sugarcane bagasse and found that the best values of biochemical methane production were obtained for hydrothermal pre-treatment. Liquid hot water or steam pretreatment is a hydrothermal pre-treatment in which water is used instead of steam. Pressure is provided to keep the water in the liquid state at elevated temperatures $\left(200-240{ }^{\circ} \mathrm{C}\right)$

Table 2 Chemical pre-treatments used for biogas production from certain agricultural substrates by means of anaerobic digestion

\begin{tabular}{|c|c|c|c|c|c|}
\hline Crop & Type & Pre-treatments & 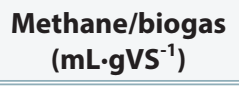 & Increased (\%) & References \\
\hline Rice straw & alkaline & $5 \mathrm{~g} \mathrm{NaOH} \cdot 100 \mathrm{~g}^{-1} ; 200^{\circ} \mathrm{C}$ & 133 & 122 & Chandra et al., 2012b \\
\hline Corn stover & alkaline & $2.5 \% \mathrm{Ca}(\mathrm{OH})_{2}$ & 260.7 & - & Ji et al., 2017 \\
\hline Wheat straw & chemical & ammonia, $0.70 \% ; 105^{\circ} \mathrm{C}$ & $538.1 \mathrm{~mL} \cdot \mathrm{g}^{-1}$ & 31.9 & Wang et al., 2019 \\
\hline Sunflower & alkaline & $55^{\circ} \mathrm{C} ; 24 \mathrm{~h} ; 4 \mathrm{~g} \mathrm{NaOH} \cdot 100 \mathrm{gTS}^{-1}$ & $191 \pm 3$ & 26 & Menardo et al., 2015 \\
\hline Barley & alkaline & $30 \mathrm{~g} \mathrm{NaOH} \cdot 100 \mathrm{~g}^{-1} ; 25^{\circ} \mathrm{C}$ & 222 & 792 & Neves et al., 2006 \\
\hline
\end{tabular}


for few minutes (Kumar et al., 2009). This method does not require rapid decompression. Considering the microwave method (steam explosion), a high temperature - from 160 to $260{ }^{\circ} \mathrm{C}$ at pressure ranging from 1 to $7 \mathrm{MPa}$ - is used to penetrate the substrate structure for a few minutes. Then, in an explosive manner, the pressure is suddenly released to allow the water molecules to escape (Sambusiti, 2013). On the other hand, hemicellulose and lignin solubilize and decompose into lightweight compounds and the secondary explosion aids structural breakdown of the residual biomass leading to finer particles (Paudel et al., 2017). In steam explosion, a quick depressurization and cooling down of the lignocellosic material take place after the steam explosion, which do not occur in steam pre-treatment (Hendriks and Zeeman, 2009). Oxidative pre-treatment, including wet oxidation, hydrogen peroxide and ozone, can enhance biogas production thanks to delignification mechanism; moreover, oxidative treatment attack the hemicellulose complex (Venturin et al., 2019). Wet oxidation is one of the methods used for hydrothermal processing, which has been used as a pre-treatment for lignocellosic materials in anaerobic digestion. The inhibitory materials of microorganisms, such as lignin (phenolics) and sugars (furans) - produced as a result of a degradation phase - can be oxidized to carboxylic acid (Klinke et al., 2002). Hydrogen is a strong oxidant and it rarely remains in secondary residues (Yu et al., 2019). It increases biodegradability of lignin, cellulose and hemicellulose. Since hydrogen peroxide promotes a non-selective oxidation process, inhibitors might be generated as lignin is oxidized to form of soluble aromatic compounds (Hendriks and Zeeman, 2009). Table 3 shows selected researches in which the combination of the pre-treatments was observed.

\section{Biological pre-treatments}

Biological pre-treatment by means of microorganisms is considered an efficient method for biodegradation promotion of lignocellulosic material (Zhao et al., 2019). There are various types of biological pre-treatments - fungal, enzymatic, ensilaging and microbial consortium - which use commercial enzymes or fungi to reduce the degree of polymerization of cellulose and partial hydrolysis of hemicellulose. Microbial consortium increases lignin degradation and methane thanks to fermentation of volatile fatty acids (Ali et al., 2017). This process is environmentally friendly because one avoids the formation of by-products and chemical-free processes by using it. It has other considerable advantages, such as the possibility to be used under mild conditions, potential methane inhibition (Howard et al., 2003), low energy consumption, and low initial investment requirements. However, this type of pre-treatment is time consuming and its application is limited. In a research, stover was pre-treated via microbial consortium by Zhao et al. (2019). The methane production increased by $62.85 \%$ and

Table 3 Combined pre-treatments used for biogas production from certain agricultural substrates by means of anaerobic digestion

\begin{tabular}{|c|c|c|c|c|c|}
\hline Crop & Category & Pre-treatment & $\begin{array}{c}\text { Produced methane/ } \\
\text { biogas }\left(\mathrm{mL} \cdot \mathrm{gVS}^{-1}\right)\end{array}$ & Increased (\%) & References \\
\hline Rice straw & $\begin{array}{l}\text { chemical plus } \\
\text { thermal }\end{array}$ & $\begin{array}{c}0.25 ; 0.5 \mathrm{M} \mathrm{Ca}(\mathrm{OH})_{2} ; 90 \\
110,130{ }^{\circ} \mathrm{C} ; 1,2,3 \mathrm{~h}\end{array}$ & $\begin{array}{c}\max : 0.5 \mathrm{M} \mathrm{Ca}(\mathrm{OH})_{2} \\
110^{\circ} \mathrm{C} ; 2 \mathrm{~h} ; 292 \mathrm{~mL} \cdot \mathrm{g}^{-1}\end{array}$ & 125 & $\begin{array}{l}\text { Dehghani et al., } \\
2015\end{array}$ \\
\hline Wheat straw & $\begin{array}{l}\text { chemical plus } \\
\text { autoclaving }\end{array}$ & $\begin{array}{c}1.5 \% \mathrm{HCl} \text {; autoclaved; } \\
121^{\circ} \mathrm{C} ; 60 \mathrm{~min}\end{array}$ & 0 & $\begin{array}{l}\text { NP* slurry }=0 \\
\text { NP solid }=0.36\end{array}$ & $\begin{array}{l}\text { Bolado-Rodríguez } \\
\text { et al., } 2016\end{array}$ \\
\hline $\begin{array}{l}\text { Sugarcane } \\
\text { bagasse }\end{array}$ & $\begin{array}{l}\text { hydrothermal plus } \\
\qquad \mathrm{Ca}(\mathrm{OH})_{2}\end{array}$ & $160,180,200,220^{\circ} \mathrm{C}$ & $\max : 318\left(180{ }^{\circ} \mathrm{C} ; 8.5 \%\right)$ & 47 & Mustafa et al., 2018 \\
\hline Maize stalks & liq hot water & $120^{\circ} \mathrm{C} ; 1 \mathrm{~h}$ & 267 & 9 & Menardo et al., 2012 \\
\hline Barley straw & liq hot water & $90^{\circ} \mathrm{C} ; 1 \mathrm{~h}$ & 340 & 42 & Menardo et al., 2012 \\
\hline
\end{tabular}

* - normalized methane production

Table 4 The optimum pre-treatments for some important agricultural crops

\begin{tabular}{|c|c|c|c|c|c|}
\hline Crop (straw) & Category & Pre-treatments & $\begin{array}{l}\text { Methane/biogas } \\
\quad\left(\mathrm{mL} \cdot \mathrm{gVS}^{-1}\right)\end{array}$ & Increased (\%) & References \\
\hline Rice & $\begin{array}{l}\text { chemical plus } \\
\text { thermal }\end{array}$ & $0.5 \mathrm{M} \mathrm{Ca}(\mathrm{OH})_{2} ; 110^{\circ} \mathrm{C} ; 2 \mathrm{~h}$ & 292 & 125 & $\begin{array}{l}\text { Dehghani et al., } \\
2015\end{array}$ \\
\hline Wheat & alkaline & $4 \% \mathrm{NaOH} ; 37^{\circ} \mathrm{C} ; 120 \mathrm{~h}$ & 165.9 & 111.6 & $\begin{array}{l}\text { Chandra et al., } \\
\qquad 2012 c\end{array}$ \\
\hline Corn & alkaline & $8 \mathrm{~g} \mathrm{NaOH} 100 \mathrm{~g}^{-1}$ substrate; $15^{\circ} \mathrm{C} ; 20$ days & 472 & 207 & $\begin{array}{l}\text { Zhong et al., } \\
\qquad 2011\end{array}$ \\
\hline $\begin{array}{l}\text { Ensiled } \\
\text { sorghum }\end{array}$ & $\begin{array}{l}\text { alkaline plus } \\
\text { thermal }\end{array}$ & $10 \% \mathrm{~g} \mathrm{NaOH} \mathrm{g}^{-1} \mathrm{TS} ; 1 \mathrm{~h}$ & 356 & 32 & $\begin{array}{l}\text { Sambusiti et al., } \\
2013\end{array}$ \\
\hline Safflower & hydrothermal & $120^{\circ} \mathrm{C} ; 1 \mathrm{~h}$ & 148.4 & $98.5 \%$ & $\begin{array}{l}\text { Hashemi et al., } \\
\qquad 2019\end{array}$ \\
\hline $\begin{array}{l}\text { Sugarcane } \\
\text { bagasse }\end{array}$ & $\begin{array}{l}\text { chemical plus } \\
\text { biological }\end{array}$ & $\begin{array}{l}2 \% \mathrm{H}_{2} \mathrm{SO}_{4}\left(\mathrm{~g} \mathrm{~L}^{-1}\right) ; 121^{\circ} \mathrm{C} ; 15 \text { min plus enzyme } \\
\text { (cellulase, hemicelluloses and } \beta \text {-glucosidase) }\end{array}$ & 200 & 208 & $\begin{array}{l}\text { Badshah et al., } \\
2012\end{array}$ \\
\hline
\end{tabular}


the activity of Methanosaeta increased from 2.0 to $10.1 \%$, indicating significant enhancement of the community ability to capture the acetic acid and reduce $\mathrm{CO}_{2}$ to methane.

Considering all kinds of aforementioned pre-treatments, a major achievement of previous studies lies in extraction of optimal pre-treatments for certain important agricultural crops, e.g. for rice straw, the highest increase in biogas production (125\%) was obtained when combined pretreatment including chemical plus thermal pre-treatments was used (Dehghani et al., 2015). The physiochemical pretreatment including chemical plus thermal pre-treatments ( $3 \% \mathrm{C}_{2} \mathrm{H}_{5} \mathrm{OH}$ and $100{ }^{\circ} \mathrm{C}$ during $60 \mathrm{~min}$ ) showed an increase by $122 \%$ in biogas production (Olugbemide et al., 2019). The combined pre-treatment including chemical plus thermal pre-treatments that used $5 \% \mathrm{NaOH}$ and $200{ }^{\circ} \mathrm{C}$ for $10 \mathrm{~min}$ showed similar increase in biogas production (Chandra et al., 2012c). For wheat straw, alkaline pre-treatment with $4 \% \mathrm{NaOH}$ resulted in an increase by $111.6 \%$ in biogas production. Optimal pre-treatments for selected important agricultural crops are given in Table 4.

\section{Conclusion}

Due to recalcitrant nature of agricultural lignocellulosic wastes, it is essential to use efficient pre-treatments prior to anaerobic digestion. There are several types of pre-treatments that are used for lignocellulosic materials, such as physical, chemical, biological and combined pretreatments. The mechanical pre-treatments are commonly utilized for particle size reduction, increasing the surface area and decreasing the technical digestion time. Conducted studies show that the physical pre-treatment combined with other pre-treatments has much better results in terms of degradability of lignocellulosic materials. Thermal or hydrothermal pre-treatments showed good results in terms of increasing anaerobic digestion degradation phase. Alkaline pre-treatments are more effective than acidic ones. Chemical pre-treatments have the advantage of easy usage, fastness, and effectiveness in comparison to other pre-treatment methods. Biological pre-treatments are environmentally friendly because there are no by-products and the process is chemical-free; however, it is time-consuming.

\section{References}

ALI, S. S. - ABOMOHRA, A. E. - SUN, J. 2017. Effective biopretreatment of sawdust waste with a novel microbial consortium for enhanced biomethanation. In Bioresource Technology, vol. 238, pp. 425-432.

ANTONOPOULOU, G. - LYBERATOS, G. 2013. Effect of pretreatment of sweet sorghum biomass on methane generation. In Waste and Biomass Valorization, vol. 4, no. 3, pp. 583-591.

BADSHAH, M. - LAM, D. M. - LIU, J. - MATTIASSON, B. 2012. Use of an automatic methane potential test system for evaluating the biomethane potential of sugarcane bagasse after different treatments. In Bioresource Technology, vol. 114, pp. 262-269.

BOLADO-RODRIGUEZ, S. - TOQUERO, C. - MARTIN-JUAREZ, J. TRAVAINI, R. GARCIA-ENCINA, P. A. 2016. Effect of thermal, acid, alkaline and alkaline-peroxide pretreatments on the biochemical methane potential and kinetics of the anaerobic digestion of wheat straw and sugarcane bagasse. In Bioresource Technology, vol. 201, pp. 182-190.
CHANDRA, R. - TAKEUCHI, H. - HASEGAWA, T. 2012a. Methane production from lignocellulosic agricultural crop wastes: A review in context to second generation of biofuel production. In Renewable and Sustainable Energy Reviews, vol. 16, no. 3, pp. 1462-1476.

CHANDRA, R. - TAKEUCHI, H. - HASEGAWA, T. 2012b. Hydrothermal pretreatment of rice straw biomass: A potential and promising method for enhanced methane production. In Applied Energy, vol. 94, pp. 129-140.

CHANDRA, R. - TAKEUCHI, H. - HASEGAWA, T. - KUMAR, R. 2012c. Improving biodegradability and biogas production of wheat straw substrates using sodium hydroxide and hydrothermal pretreatments. In Energy, vol. 43, no. 1, pp. 273-282.

CHEN, X. - GU, Y. - ZHOU, X. - ZHANG, Y. 2014. Asparagus stem as a new lignocellulosic biomass feedstock for anaerobic digestion: Increasing hydrolysis rate, methane production and biodegradability by alkaline pretreatment. In Bioresource Technology, vol. 164, pp. 78-85.

CHEN, Y. - CHENG, J. J. - CREAMER, K. S. 2008. Inhibition of anaerobic digestion process: A review. In Bioresource Technology, vol. 99, no. 10, pp. 4044-4064.

CHOJNACKA, A. - SZCZĘSNY, P. - BŁASZCZYK, M. K. - ZIELENKIEWICZ, U. - DETMAN, A. - SALAMON, A. - SIKORA, A. 2015. Noteworthy facts about a methane-producing microbial community processing acidic effluent from sugar beet molasses fermentation. In PLoS One, vol. 10, no. 5, pp. e0128008.

COSTA, A. - PINHEIRO, G. - PINHEIRO, F. - DOS SANTOS, A. SANTAELLA, S. - LEITÃO, R. 2014. The use of thermochemical pretreatments to improve the anaerobic biodegradability and biochemical methane potential of the sugarcane bagasse. In Chemical Engineering Journal, vol. 248, pp. 363-372.

DEHGHANI, M. - KARIMI, K. - SADEGHI, M. 2015. Pretreatment of rice straw for the improvement of biogas production. In Energy \& Fuels, vol. 29. no. 6, pp. 3770-3775.

GRÖNROOS, A. - PIRKONEN, P. - RUPPERT, O. 2004. Ultrasonic depolymerization of aqueous carboxymethylcellulose. In Ultrasonics Sonochemistry, vol. 11, no. 1, pp. 9-12.

GU, Y. - ZHANG, Y. - ZHOU, X. 2015. Effect of $\mathrm{Ca}(\mathrm{OH})_{2}$ pretreatment on extruded rice straw anaerobic digestion. In Bioresource Technology, vol. 196, pp. 116-122.

HASHEMI, S. S. - KARIMI, K. - MIRMOHAMADSADEGHI, S. 2019. Hydrothermal pretreatment of safflower straw to enhance biogas production. In Energy, vol. 172, pp. 545-554.

HE, Y. - PANG, Y. - LIU, Y. - LI, X. - WANG, K. 2008. Physicochemical characterization of rice straw pretreated with sodium hydroxide in the solid state for enhancing biogas production. In Energy \& Fuels, vol. 22, no. 4, pp. 2775-2781.

HENDRIKS, A. - ZEEMAN, G. 2009. Pretreatments to enhance the digestibility of lignocellulosic biomass. In Bioresource Technology, vol. 100, no. 1, pp. 10-18.

HJORTH, M. - GRÄNITZ, K. - ADAMSEN, A. P. - MØLLER, H. B. 2011. Extrusion as a pretreatment to increase biogas production. In Bioresource Technology, vol. 102, no. 8, pp. 4989-4994.

HLINKA, P. - KARANDUŠOVSKÁ, I. - MIHINA, Š. 2019. Monitoring of gas production during the biowaste composting. In Acta Technologica Agriculturae, vol. 22, no. 3, pp. 75-79.

HOWARD, R. - ABOTSI, E. - VAN RENSBURG, E. J. - HOWARD, S. 2003. Lignocellulose biotechnology: Issues of bioconversion and enzyme production. In African Journal of Biotechnology, vol. 2, no. 12, pp. 602-619.

JI, J. - ZHANG, J. - YANG, L. - HE, Y. - ZHANG, R. - LIU, - G. CHEN, C. 2017. Impact of co-pretreatment of calcium hydroxide and steam explosion on anaerobic digestion efficiency with corn stover. In Environmental Technology, vol. 38, no. 12, pp. 1465-1473.

KARUPPIAH, T. - AZARIAH, V. E. 2019 Biomass pretreatment for 
enhancement of biogas production. In Anaerobic Digestion. IntechOpen CY - Rijeka.

KAŽIMÍROVÁ, V. - GADUŠ, J. - GIERTL,T. 2018. Verification of suitability of substrate composition for production and quality of biogas. In Acta Technologica Agriculturae, vol. 21, no. 3, pp. 115-118.

KLINKE, H. B. - AHRING, B. K. - SCHMIDT, A. S. - THOMSEN, A. B. 2002. Characterization of degradation products from alkaline wet oxidation of wheat straw. In Bioresource Technology, vol. 82, no. 1, pp. 15-26.

KUMAR, P. - BARRETT, D. M. - DELWICHE, M. J. - STROEVE, P. 2009. Methods for pretreatment of lignocellulosic biomass for efficient hydrolysis and biofuel production. In Industrial \& Engineering Chemistry Research, vol. 48, no. 8, pp. 3713-3729.

LI, C. - CHAMPAGNE, P. - ANDERSON, B. C. 2013. Effects of ultrasonic and thermo-chemical pre-treatments on methane production from fat, oil and grease (FOG) and synthetic kitchen waste (KW) in anaerobic co-digestion. In Bioresource Technology, vol. 130, pp. 187-197.

MENARDO, S. - AIROLDI, G. - BALSARI, P. 2012. The effect of particle size and thermal pre-treatment on the methane yield of four agricultural by-products. In Bioresource Technology, vol. 104, pp. 708-714.

MENARDO, S. - CACCIATORE, V. - BALSARI, P. 2015. Batch and continuous biogas production arising from feed varying in rice straw volumes following pre-treatment with extrusion. In Bioresource Technology, vol. 180, pp. 154-161.

MONTGOMERY, L. F. - BOCHMANN, G. 2014. Pretreatment of feedstock for enhanced biogas production. IEA Bioenergy Ireland. MUSSOLINE, W. - ESPOSITO, G. - GIORDANO, A. - LENS, P. 2013. The anaerobic digestion of rice straw: A review. In Critical Reviews in Environmental Science and Technology, vol. 43, no. 9, pp. 895-915. MUSTAFA, A. M. - LI, H. - RADWAN, A. A. - SHENG, K. - CHEN, X. 2018. Effect of hydrothermal and $\mathrm{Ca}(\mathrm{OH})_{2}$ pretreatments on anaerobic digestion of sugarcane bagasse for biogas production. In Bioresource Technology, vol. 259, pp. 54-60.

NEVES, L. - RIBEIRO, R. - OLIVEIRA, R. - ALVES, M. 2006. Enhancement of methane production from barley waste. In Biomass and Bioenergy, vol. 30, no. 6, pp. 599-603.

OLUGBEMIDE, A. D. - LAJIDE, L. - ADEBAYO, A. - OWOLABI, B. J. 2019 Enhanced biogas production from rice husk through solid-state chemical pretreatments. In Waste and Biomass Valorization, pp. 1-11. PANEPINTO, D. - GENON, G. 2016. Analysis of the extrusion as a pretreatment for the anaerobic digestion process. In Industrial Crops and Products, vol. 83, pp. 206-212.

PAUDEL, S. R. - BANJARA, S. P. - CHOI, O. K. - PARK, K. Y. - KIM, Y. M. LEE, J. W. 2017. Pretreatment of agricultural biomass for anaerobic digestion: Current state and challenges. In Bioresource Technology, vol. 245 , pp. 1194-1205.

RAl, G. 1986. Non-Conventional Energy Sources. Delhi: Khanna Publishers, 696 pp. ISBN 9788174090737.

RAJPUT, A. A. - VISVANATHAN, C. 2018. Effect of thermal pretreatment on chemical composition, physical structure and biogas production kinetics of wheat straw. In Journal of Environmental Management, vol. 221, pp. 45-52.

SALEHIAN, P. - KARIMI, K. - ZILOUEI, H. - JEIHANIPOUR, A. 2013. Improvement of biogas production from pine wood by alkali pretreatment. In Fuel, vol. 106, pp. 484-489.

SAMBUSITI, C. 2013. Physical, chemical and biological pretreatments to enhance biogas production from lignocellulosic substrates. Doctoral dissertation, 209 pp., Polytechnic University of Milan.

SAMBUSITI, C. - MONLAU, F. - FICARA, E. - CARRÈRE, H. - MALPEI, F. 2013. A comparison of different pre-treatments to increase methane production from two agricultural substrates. In Applied Energy, vol. 104, pp. 62-70.

SIMO, W. S. F. - JONG, E. N. - KAPSEU, C. 2016. Improving biogas production of sugarcane bagasse by hydrothermal pretreatment. In Chemical and Biomolecular Engineering, vol. 1, no. 3, 21-25.
SINGH, J. - SUHAG, M. - DHAKA, A. 2015. Augmented digestion of lignocellulose by steam explosion, acid and alkaline pretreatment methods: A review. In Carbohydrate Polymers, vol. 117, pp. 624-631. TU, W. C. - HALLETT, J. P. 2019. Recent advances in the pretreatment of lignocellulosic biomass. In Current Opinion in Green and Sustainable Chemistry, vol. 20, pp. 11-17.

VENTURIN, B. - BONATTO, C. - DAMACENO, F. M. - MULINARI, J. FONGARO, G. - TREICHEL, H. 2019 Physical, chemical, and biological substrate pretreatments to enhance biogas yield. In Improving Biogas Production. Springer, pp. 25-44.

WANG, D. SHEN, F. - YANG, G. - ZHANG, Y. - DENG, S. - ZHANG, J. - ZENG, Y. - LUO, T. - MEI, Z. 2018. Can hydrothermal pretreatment improve anaerobic digestion for biogas from lignocellulosic biomass. In Bioresource Technology, vol. 249, pp. 117-124.

WANG, D. - XIN, Y. - SHI, H. - Al, P. - YU, L. - LI, X. - CHEN, S. 2019. Closing ammonia loop in efficient biogas production: Recycling ammonia pretreatment of wheat straw. In Biosystems Engineering, vol. 180, pp. 182-190.

WANG, L. - MATTSSON, M. - RUNDSTEDT, J. - KARLSSON, N. 2011. Different pretreatments to enhance biogas production. Master of Science thesis, Halmstad University.

XIE, S. - FROST, J. P. - LAWLOR, P. G. - WU, G. - ZHAN, X. 2011. Effects of thermo-chemical pre-treatment of grass silage on methane production by anaerobic digestion. In Bioresource Technology, vol. 102, no. 19, pp. 8748-8755.

YU, Q. - LIU, R. - LI, K. - MA, R. 2019. A review of crop straw pretreatment methods for biogas production by anaerobic digestion in China. In Renewable and Sustainable Energy Reviews, vol. 107, pp. 51-58.

YU, J. - ZHANG, J. - HE, J. - LIU, Z. - YU, Z. 2009. Combinations of mild physical or chemical pretreatment with biological pretreatment for enzymatic hydrolysis of rice hull. In Bioresource Technology, vol. 100, no. 2, pp. 903-908.

YUAN, X. - WEN, B. - MA, X. - ZHU, W. - WANG, X. - CHEN, S. - CUI, Z. 2014. Enhancing the anaerobic digestion of lignocellulose of municipal solid waste using a microbial pretreatment method. In Bioresource Technology, vol. 154, pp. 1-9.

ZEYNALI, R. - KHOJASTEHPOUR, M. - EBRAHIMI-NIK, M. 2017. Effect of ultrasonic pre-treatment on biogas yield and specific energy in anaerobic digestion of fruit and vegetable wholesale market wastes. In Sustainable Environment Research, vol. 27, no. 6, pp. 259-264.

ZHAO, H. - JONES, C. L. - BAKER, G. A. - XIA, S. - OLUBAJO, O. PERSON, V. N. 2009. Regenerating cellulose from ionic liquids for an accelerated enzymatic hydrolysis. In Journal of Biotechnology, vol. 139, no. 1, pp. 47-54.

ZHAO, Y. - XU, C. - Al, S. - WANG, H. - GAO, Y. - YAN, L. - MEI, Z. WANG, W. 2019. Biological pretreatment enhances the activity of functional microorganisms and the ability of methanogenesis during anaerobic digestion. In Bioresource Technology, pp. 121660. ZHENG, M. - LI, L. - LI, X. - XIONG, J. - MEI, T. - CHEN, G. 2010. The effects of alkaline pretreatment parameters on anaerobic biogasification of corn stover. In Energy Sources, Part A: Recovery, Utilization, and Environmental Effects, vol.32, no. 20, pp. 1918-1925. ZHENG, Y. - ZHAO, J. - XU, F. - LI, Y. 2014. Pretreatment of lignocellulosic biomass for enhanced biogas production. In Progress in Energy and Combustion Science, vol. 42, pp. 35-53.

ZHONG, W. - ZHANG, Z. - QIAO, W. - FU, P. - LIU, M. 2011. RETRACTED: Comparison of chemical and biological pretreatment of corn straw for biogas production by anaerobic digestion. In Renewable Energy, vol. 36, no. 6, pp. 1875-1879.

ZILOUEI, H. - TAHERDANAK, M. 2015 Biohydrogen from lignocellulosic wastes. In Lignocellulose-based bioproducts. Springer, pp. 253-288. 